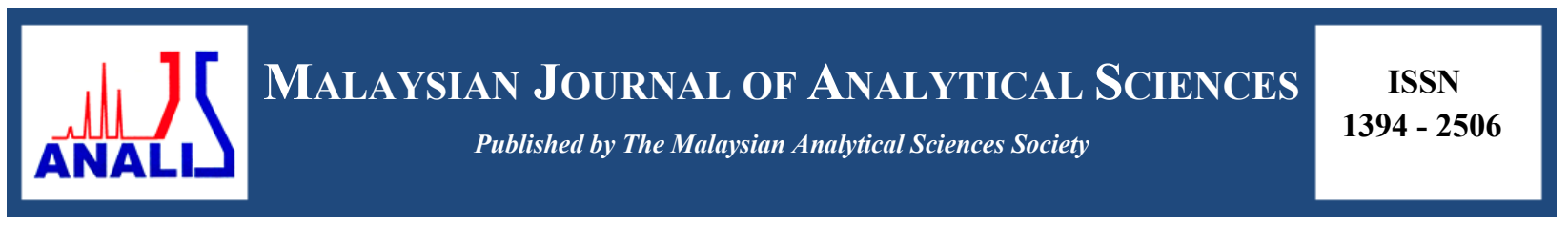

\title{
ASSESSING STIR BAR SORPTIVE EXTRACTION FOR TRIAZINE HERBICIDES EXTRACTION BY USING A CENTRAL COMPOSITE DESIGN APPROACH
}

\author{
(Penilaian Pengekstrakan Erapan Bar untuk Pengekstrakan Herbisid Triazin Menggunakan \\ Pendekatan Reka Bentuk Komposit Berpusat) \\ Nurul Auni Zainal Abidin ${ }^{1,2 *}$, Md Pauzi Abdullah ${ }^{1,3}$, Fouad Fadhil Al-Qaim ${ }^{1,4,5}$, \\ Wan Mohd Afiq Wan Mohd Khalik ${ }^{3,6}$, Mohamed Rozali Othman ${ }^{1,3}$

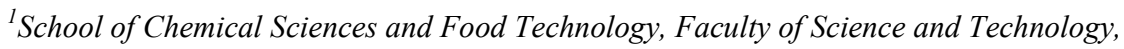 \\ Universiti Kebangsaan Malaysia, 43600 UKM Bangi, Selangor, Malaysia \\ ${ }^{2}$ Faculty of Applied Sciences, \\ Universiti Teknologi MARA Negeri Sembilan, Kuala Pilah Campus, 72000 Kuala Pilah, Negeri Sembilan, Malaysia \\ ${ }^{3}$ Centre for Water Research and Analysis (ALIR), Faculty of Science and Technology, \\ Universiti Kebangsaan Malaysia, 43600 UKM Bangi, Selangor, Malaysia \\ ${ }^{4}$ Department of Chemistry, Faculty of Science for Women, \\ University of Babylon, PO Box 4, Hilla, Iraq \\ ${ }^{5}$ Department of Environmental Engineering and Green Technology, Malaysia-Japan International Institute of Technology, \\ Universiti Teknologi Malaysia, 54100 Kuala Lumpur, Malaysia. \\ ${ }^{6}$ School of Marine and Environmental Sciences, \\ Universiti Malaysia Terengganu, 21030 Kuala Nerus, Terengganu, Malaysia \\ *Corresponding author: nurulauni@ns.uitm.edu.my
}

Received: 24 October 2017; Accepted: 4 January 2018

\begin{abstract}
A (PDMS)-coated stir bar was prepared for a glass jacket-free stir bar sorptive extraction (SBSE) configuration by adhesion technique for the extraction of triazine herbicides prior to quantification using a gas chromatography-flame ionization detector (GC-FID). A central composite design (CCD) was used in the optimization of extraction and desorption conditions. At optimum conditions, values of factors were set as $\mathrm{pH} \mathrm{8.5,} \mathrm{with} \mathrm{no} \mathrm{addition} \mathrm{of} \mathrm{NaCl}$, for 25 minutes of extraction time, and 24 minutes of desorption time. Under optimal experimental conditions, the proposed method has linear ranges at $0.1-100 \mu \mathrm{gL}^{-1}$ with correlation of determination $\left(\mathrm{R}^{2}\right)$, ranging from $0.9991-0.9995$, respectively. The limit of detection (LODs) and limit of quantification (LOQs) of three triazines were found to be ranging from $0.015-0.023 \mu \mathrm{gL}^{-1}$ and $0.047-0.060 \mu \mathrm{gL}^{-1}$, respectively.
\end{abstract}

Keywords: stir bar sorptive extraction, triazine herbicides, central composite design, partition coefficient

\begin{abstract}
Abstrak
Bar berputar yang disalut dengan polidimetilsiloksana (PDMS) telah disediakan untuk pengekstrakan erapan bar berputar (SBSE) tanpa jaket kaca melalui teknik lekatan untuk dianalisa sebelum kuantifikasi racun herbisid triazin dengan menggunakan kromatografi gas-pengesan ionisasi nyala (GC-FID). Reka bentuk komposit berpusat (CCD) telah digunakan untuk proses pengoptimuman keadaan pengekstrakan dan nyahjerapan. Pada keadaan optimum, nilai faktor adalah $\mathrm{pH} 8.5$, tanpa penambahan $\mathrm{NaCl}, 25$ minit masa pengekstrakan, dan masa nyahjerapan 24 minit. Kajian berdasarkan julat kelinearan antara $0.1-100 \mu \mathrm{gL}^{-1}$
\end{abstract}


telah mencapai kelinearan yang baik dengan pekali $\mathrm{R}^{2}$ di rekod antara $0.9991-0.9995$. Had pengesanan (LODs) dan kuantifikasi (LOQs) bagi tiga jenis triazin tersebut masing- masing dihitung antara $0.015-0.023 \mu \mathrm{gL}^{-1}$ dan $0.047-0.060 \mu \mathrm{gL}^{-1}$.

Kata kunci: pengekstrakan erapan bar berputar, herbisid triazin, reka bentuk komposit berpusat, pemalar pemisahan

\section{Introduction}

Since their introduction, triazine herbicides have been widely used in agriculture as selective herbicides in many parts of world. These herbicides and their degradation products are highly persistent and hence their analysis in environmental samples is important [1]. The concentration of triazines in aquatic environments like ground water, rivers and estuaries is often found to be close to the lower detection limits of most elaborate analytical procedures [2]. Therefore, in order to protect human health and the environment, it is significantly important to monitor their levels in environmental waters. This has increased the demand for the development of simple, reliable, sensitive and rapid analytical methods. Sample preparation is considered as the most critical step in the overall analytical process since it plays a key role in analyte extraction, pre-concentration, and cleanup [3].

Conventional liquid-liquid extraction (LLE) and solid-phase extraction (SPE) have been used for pre-concentration and cleanup before analysis. LLE is time-consuming and hazardous to health due to the high volume of toxic solvents used [4]. SPE needs less solvent but it is still time consuming, and often requires a concentration stage that presents disadvantages such as loss in the evaporation step [5].

However, modern trends in analytical chemistry are moving towards the simplification and miniaturization of sample preparation, as well as the minimization of organic solvent used. Stir bar sorptive extraction (SBSE), as a microextraction method, was first introduced by Baltussen et al. in 1999 [6]. This technique has gained wide acceptance as a highly efficient sample preparation method for enrichment of solutes from aqueous samples [7]. The extraction is controlled by the solutes partitioning coefficient between the polymer coating and the sample matrix and by the phase ratio between the polymer coating and the sample volume. For a polydimethylsiloxane coating and aqueous samples, this partitioning coefficient resembles the octanol-water partitioning coefficient. In comparison to solid phase micro-extraction, a larger amount of sorptive extraction phase is used, and consequently, very high sensitivities in environmental, food and biomedical fields trace analysis. SPME and SBSE have been compared for the analysis of different compounds, as organochlorine pesticides [8] and organophosphorus insecticides [9]. All the studies reached the same conclusion, whereby the SBSE concentration capability was better than those presented by SPME because of polydimethylsiloxane (PDMS) film phase that covers the bar is thicker.

In the SBSE technique, the sample is stirred with a glass enclosed magnetic stir bar coated with a layer of PDMS, resulting in a distribution of analytes between the aqueous sample matrix and the PDMS layer [3]. The glass jacket is useful to immobilize sorbents onto the stir bar but it may lead to low stability and reproducibility because the glass jacket is relatively fragile. In this work, we introduced a glass jacket-free SBSE configuration by introducing a low cost hollow glass cylinder as a template for coating the SBSE polymeric phase. This template is important for reproducing the same bar characteristics from batch to batch.

Thus, this work aims to develop the prepared homemade glass jacket-free SBSE using PDMS sorbent for the determination of the selected triazine herbicides at trace levels from water samples prior to their determination by gas chromatography-flame ionization detector (GC-FID). An experimental design was used to investigate the influence of the principal parameters affecting glass jacket-free SBSE extraction of triazines. Thus, for determining the best experimental conditions, a central composite design (CCD) was applied. The developed method was then tested using different quality control approaches including detection limit and recovery assay.

\section{Chemicals and reagents}

\section{Materials and Methods}

Triazines namely atrazine, cyanazine, and ametryn, were purchased from Dr. Ehrenstorfer (GmBH, Germany). A standard compound solution at $1000 \mathrm{mgL}^{-1}$ each were prepared in methanol. The mixture of all the compounds was prepared by diluting the standard solution in ultrapure water. All standard stock solutions were kept in a refrigerator 
at $4{ }^{\circ} \mathrm{C}$. HPLC-grade methanol, acetonitrile, acetic acid and hydrochloric acid were purchased from Merck (Darmstadt, Germany). Sodium chloride and sodium hydroxide were of analytical grade and obtained from R \& M (Essex, UK). Ultrapure water was purified by Milli-Q EasypureRodi system (Barnstead, USA). PDMS Sylgard 184 silicone elastomer kit, which comprised base/curing agent to be mixed in a ratio of 10 (base) to 1 (curing agent) was obtained from Sigma Aldrich (St. Louis, USA).

\section{Gas chromatographic analysis}

A gas chromatography (GC) model HP 5890 Series II system equipped with a flame ionization detector (FID) (Hewlett-Packard) was used in this work. An Agilent DB-5 capillary column $(30 \mathrm{~m}$ x $0.32 \mathrm{~mm}$ i.d. x $1.50 \mu \mathrm{m}$ film thickness) was employed for the chromatographic separation. Helium was used as carrier gas at a flow rate of 1.0 $\mathrm{mL} \mathrm{min}^{-1}$. The $\mathrm{GC}$ oven temperature was programmed as follows: initial temperature was held at $120^{\circ} \mathrm{C}$ for $1 \mathrm{~min}$, programmed at $30{ }^{\circ} \mathrm{C} \mathrm{min}{ }^{-1}$ to $180{ }^{\circ} \mathrm{C}$ and kept at this temperature for $1 \mathrm{~min}$, then $10{ }^{\circ} \mathrm{C} \mathrm{min}^{-1}$ to $250{ }^{\circ} \mathrm{C}$ and kept at this temperature for $3 \mathrm{~min}$. The total run time was $15.00 \mathrm{~min}$. The injection port and detector temperature were both set at $250{ }^{\circ} \mathrm{C}$ and $280{ }^{\circ} \mathrm{C}$, respectively. Sample $(1 \mu \mathrm{L})$ was manually injected into the injection port under the splitless mode.

\section{Experimental design of PDMS stir bar sorptive extraction procedure}

The glass jacket-free SBSE conditions were optimized by using a CCD (with $\alpha=2.000$ ), based on $2^{4}$ factorial design plus eight axial points plus six replicates in the centre of the design. The variables chosen for SBSE optimization were $\mathrm{pH}$ of the sample solution, ionic strength, extraction time, and desorption time. The factors, their levels, and symbols that were investigated by CCD are shown in Table 1.30 experiments were generated by CCD and executed in a randomized order. The data were processed using Minitab version 17 (Minitab Inc. USA).

Table 1. Design matrix for central composite design

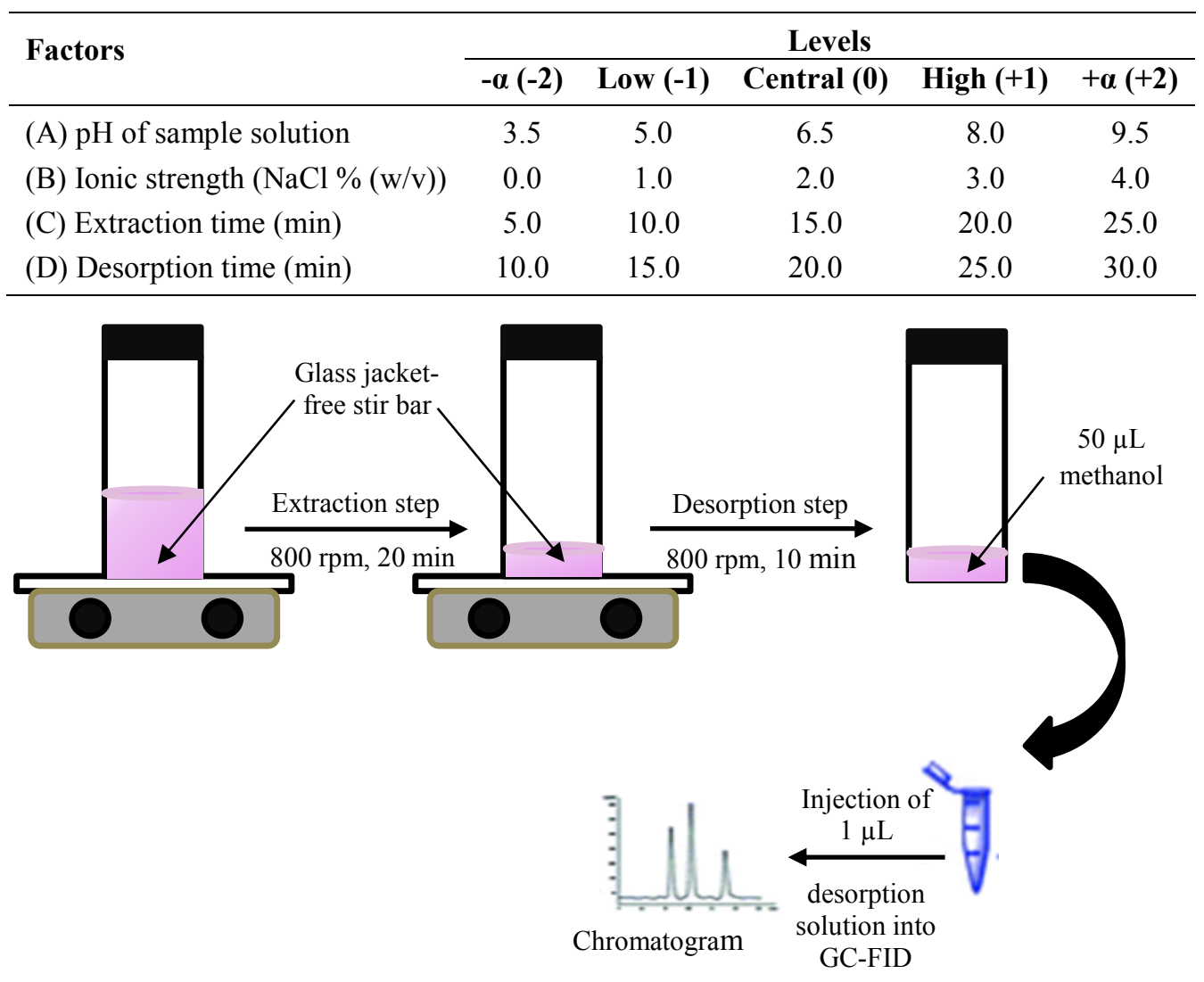

Figure 1. Schematic illustration of glass jacket-free SBSE process 
In principle, the extractions were carried out with the homemade PDMS stir bar in a $25-\mathrm{mL}$ amber glass vial, containing $10 \mathrm{~mL}$ standard solution of three selected triazines, and according to the experimental factorial design matrix. The vial was placed on the constant temperature magnetic stirrer. The stir bar was immersed into the standard solution and stirred at $800 \mathrm{rpm}$ for 20 minutes. After extraction, the modified stir bar was removed, dried on a clean lint-tissue and transferred into a cylindrical glass desorption vial containing $50 \mu \mathrm{L}$ methanol to desorb the targeted triazines under a magnetic stirring rate of $800 \mathrm{rpm}$ for 10 minutes. Then, $1 \mu \mathrm{L}$ of desorption solution was injected to the GC-FID injection port for analysis. The stir bar was regenerated in $0.5 \mu \mathrm{L}$ methanol under ultrasonication for 15 minutes before the next use. Finally, a numerical data analysis resulting from CCD suggested that the optimum conditions were set as: $8.5(\mathrm{pH})$, no addition of $\mathrm{NaCl}, 25 \mathrm{~min}$ (extraction time), and 24 min (desorption time).

\section{Method validation}

Analytical performance of the proposed stir bar was validated in terms of repeatability, linearity, limit of detection (LOD), and limit of quantification (LOQ) using the optimized extraction conditions. The linearity was obtained from the construction of calibration curve from $0.1-100 \mu \mathrm{gL}^{-1}$ with triplicate measurements. LOD was determined at signal-to-noise ratio $(\mathrm{S} / \mathrm{N}=3)$ whilst the $\mathrm{LOQ}$ was determined at signal-to-noise ratio $(\mathrm{S} / \mathrm{N}=10)$. Repeatability of the methods was evaluated by performing nine measurements (three concentrations/three replicates) encompassing the concentration range, and calculating the relative standard deviations (RSD).

\section{Quantification of partition coefficient and enrichment factor}

At equilibrium, the partition coefficient for the analyte is dependent upon the phase ratio, and thus on the amount of extraction phase used as shown in equation 1.

$$
K=\frac{C_{e, e q}}{c_{s, e q}}=\frac{m_{e}}{m_{s}} \times \frac{V_{s}}{V_{e}}=\frac{m_{e}}{m_{s}} \times \beta
$$

The distribution coefficient between the extraction phase used and the sample is defined as the ratio between the analyte concentrations in the extraction phase $\left(\mathrm{C}_{\mathrm{e}, \mathrm{eq}}\right)$ over the concentration of the analyte in the sample $\left(\mathrm{C}_{\mathrm{s}, \mathrm{eq}}\right)$ at equilibrium. This ratio is equal to the ratio of the mass of the analyte in the extraction phase $\left(\mathrm{m}_{\mathrm{e}}\right)$ over the mass of the analyte in the sample $\left(\mathrm{m}_{\mathrm{s}}\right)$ times the phase ratio $\beta$, which is defined as the ratio between the volume of the sample $\left(\mathrm{V}_{\mathrm{s}}\right)$ over the volume of the extraction phase $\left(\mathrm{V}_{\mathrm{e}}\right)$. According to the mass balance relationship (equation 2):

$$
C_{t} \cdot V_{s}=C_{e, e q} \cdot V_{e}+C_{s, e q} \cdot V_{s}
$$

where $C_{t}$ is the original concentration of analytes. The enrichment factor, $E F$, can be defined as the ratio of the equilibrium concentration of analytes in the extraction phase to the original concentration of analytes in the sample. $\mathrm{EF}$ can be calculated from equation 3 :

$$
E F=\frac{C_{e, e q}}{C_{t}}=\frac{1}{\left(\frac{V_{e}}{V_{S}}+\frac{1}{K}\right)}
$$

\section{Central composite design}

\section{Results and Discussion}

Based on the above results, a $2^{4}$ of CCD was performed at five levels to optimize the factors $\mathrm{pH}$, ionic strength, extraction time, and desorption time in order to improve the extraction recovery (ER\%) percentage of of triazines. The stirring speed and volume of desorption solvent were held constant at $800 \mathrm{rpm}$ and $300 \mu \mathrm{L}$. The CCD was used not only to evaluate the variables significance, but also to analyze the interaction among them. A quadratic regression model, on the basis of a multiple linear regression (MLR), should be applied to relate the responses and the variables. The second order polynomial equation obtained using coded value is given in regression in Equation 4: 


$$
\begin{aligned}
\mathrm{ER}= & 66.44+6.865 \mathrm{~A}-5.512 \mathrm{~B}+10.674 \mathrm{C}+5.396 \mathrm{D}-6.880 \mathrm{~A}^{2}-1.768 \mathrm{~B}^{2}-3.568 \mathrm{C}^{2}-4.226 \mathrm{D}^{2} \\
& +4.12 \mathrm{AB}+6.07 \mathrm{AC}-5.49 \mathrm{BC}
\end{aligned}
$$

where, $\mathrm{A}, \mathrm{B}, \mathrm{C}$ and $\mathrm{D}$ are the $\mathrm{pH}$, ionic strength, extraction time and desorption time, respectively. As shown in the equation, the developed model consisted of four main effects, four curvature effects, and three interaction effects. Variables A, C, D, and interaction effects of $\mathrm{AB}$ and $\mathrm{AC}$ had positive linearity toward the fitted model.

To evaluate the significance of each factor and interaction terms, analysis of variance (ANOVA) was used and the obtained results are presented in Table 2 . The quality of fit of the model equation was represented by the coefficient of determination ( $\mathrm{R}^{2}$ and adjusted- $\mathrm{R}^{2}$ ). $\mathrm{R}^{2}$ of 0.9651 and adjusted- $\mathrm{R}^{2}$ of 0.9538 showed a good relationship between the experimental data and fitted model, as well as the high potential of model in prediction of response. The Pvalues were used to check the statistical significance of each coefficient, which in turn was necessary to understand the pattern of the mutual interactions between the test variables. Furthermore, P-value lower than 0.05 indicates the statistical significance of an effect at $95 \%$ confidence level. In this study, all individual experimental factors were significant with P-value $<0.05$.

The other criterion for evaluating the model is the lack of fit (LOF) test which was performed by comparing the residual with the pure error achieved from the replicated design points at the central level of variables. In this case, if the P-value was greater than 0.05 (at the significance level of 95\%), the regression will be significant. Considering the ANOVA results from Table 2, the P-value of the LOF test was 0.799, which confirms the lack of fit insignificance.

Table 2. Analysis of variance (ANOVA) for the developed models

\begin{tabular}{llcccc}
\hline Source & Df $^{\text {a }}$ & Sum of Square & Mean Square & F-value & P-value \\
\hline Model & 11 & 8365.69 & 760.52 & 45.25 & 0.000 \\
Blocks & 1 & 64.0 & 64.0 & 4.77 & 0.043 \\
$\mathrm{~A}$ & 1 & 1131.17 & 1131.17 & 67.30 & 0.001 \\
$\mathrm{~B}$ & 1 & 729.30 & 729.30 & 43.39 & 0.000 \\
$\mathrm{C}$ & 1 & 2734.22 & 2734.22 & 162.67 & 0.002 \\
$\mathrm{D}$ & 1 & 698.76 & 698.76 & 41.57 & 0.000 \\
$\mathrm{~A}^{2}$ & 1 & 1298.39 & 1298.39 & 77.25 & 0.001 \\
$\mathrm{~B}^{2}$ & 1 & 85.71 & 85.71 & 5.10 & 0.037 \\
$\mathrm{C}^{2}$ & 1 & 349.13 & 349.13 & 20.77 & 0.003 \\
$\mathrm{D}^{2}$ & 1 & 489.86 & 489.86 & 29.14 & 0.000 \\
$\mathrm{AB}$ & 1 & 271.43 & 271.43 & 16.15 & 0.001 \\
$\mathrm{AC}$ & 1 & 590.09 & 590.09 & 35.11 & 0.000 \\
BC & 1 & 482.17 & 482.17 & 28.69 & 0.000 \\
LOF $^{\mathrm{b}}$ & 13 & 202.86 & 14.49 & 0.58 & 0.799 \\
Pure error & 4 & 99.69 & 24.92 & & \\
Total & 29 & 8668.24 & & & \\
\hline
\end{tabular}

${ }^{\mathrm{a}}$ Degree of freedom, ${ }^{\mathrm{b}}$ Lack of fit, and bold value is significant at $\mathrm{p}<0.05$ 


\section{Effect of variables on extraction efficiency}

The matrix $\mathrm{pH}$ and ionic strength variables affect the extraction thermodynamics, so influencing the interaction between the analytes and the PDMS phase. The $\mathrm{pH}$ of the sample solution plays an important role for ionizable compounds such as triazines. Triazines are basic herbicides, and it is assumed that at a basic $\mathrm{pH}$ condition, better extraction recovery will be obtained.

In this work, $\mathrm{pH}$ values ranging from 3.5 to 9.5 were investigated. Triazine compounds contain amino groups and their existing forms will be affected by medium $\mathrm{pH}$. It can be seen from the figure that at low $\mathrm{pH}$ values, the extraction efficiencies are low because the nitrogen atoms of triazines were protonated. Therefore, the molecules of trizaines were in ionic form, resulting in only $\pi-\pi$ interaction that contributed to the extraction. With the increase of $\mathrm{pH}$ value, hydrophobic interaction also contributed to the extraction because triazines existed in a neutral form. According to the polynomial equation (equation 1) and response surface plot (Figure 2 (a)), the $\mathrm{pH}$ variables were significant with a positive sign, showing an increase of extraction recovery due to the increase in $\mathrm{pH}$ value, reaching the maximum at $\mathrm{pH} 8.5$ and then decreasing after that. Lei et al. [10] applied polydimethylsiloxane (PDMS)/MIL$100(\mathrm{Fe})$ coated stir bar for the determination of six triazines (simazine, atrazine, prometon, ametryn, prometryne and prebane) and observed that $\mathrm{pH} 8$ was the optimum $\mathrm{pH}$ for their study.
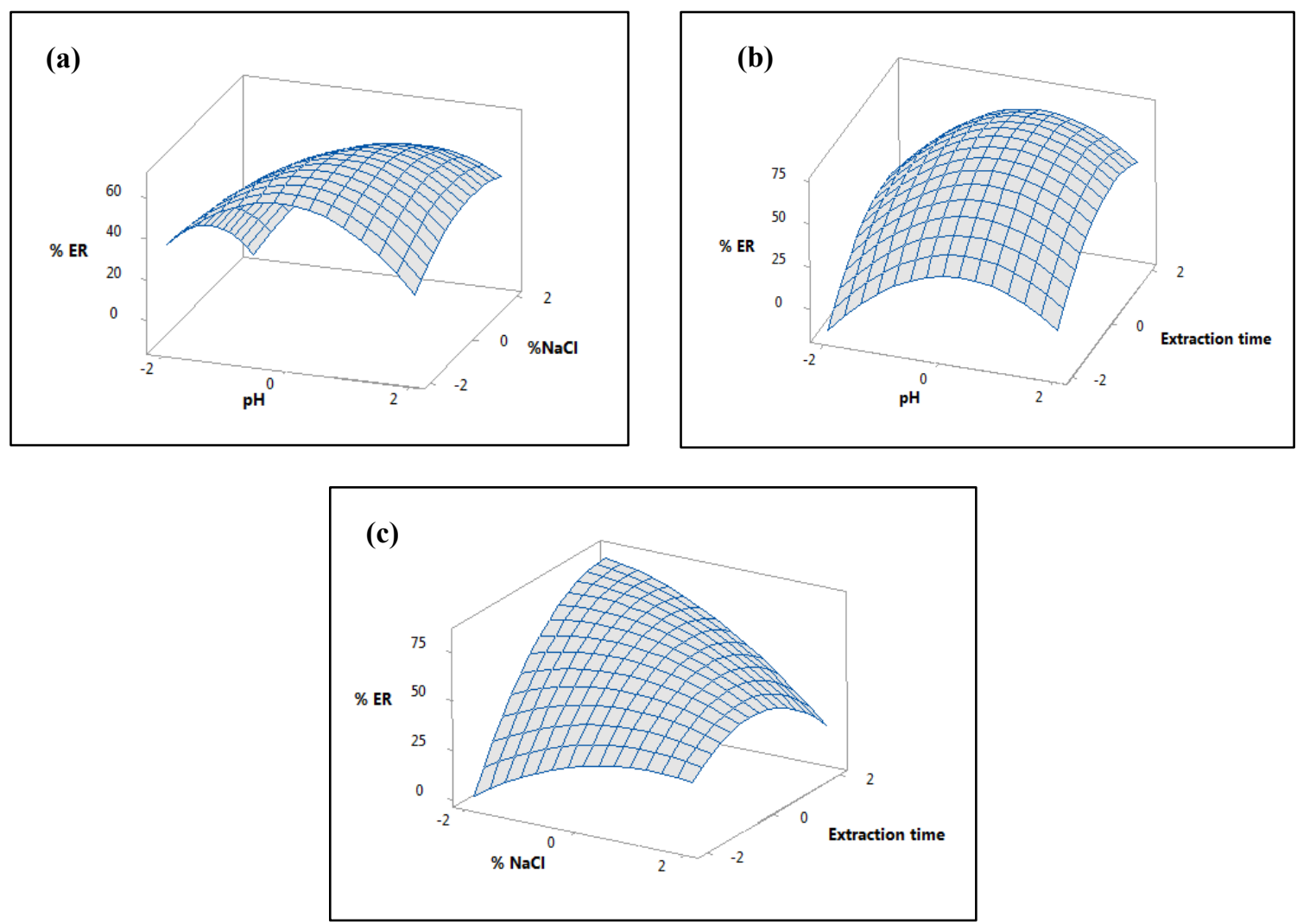

Figure 2. Response surface plots of total extraction recovery as a function of (a) $\mathrm{pH} v s \mathrm{NaCl}$, (b) $\mathrm{pH} v s$ extraction time and (c) extraction time $v s \mathrm{NaCl}$

However, inert salts, such as sodium chloride, were added during SBSE in order to modify the ionic strength of the sample solution. It has been observed that the addition of inert salt does not improve, but even reduce, the extraction efficiency for hydrophobic analytes $\left(\log \mathrm{K}_{\mathrm{o} / \mathrm{w}}>3\right)$ [11]. In contrast, for polar analytes $\left(\log \mathrm{K}_{\mathrm{o} / \mathrm{w}}<3\right.$ ), the extraction efficiency increased with the addition of salts. Since the $\log \mathrm{K}_{\mathrm{o} / \mathrm{w}}$ for atrazine, ametryn, and cyanazine was 2.61, 2.98 , and 2.22, respectively, they can be considered as semi polar analytes and the addition of the inert salt was 
investigated. Apart from $\mathrm{pH}$ adjustment, salt addition showed a significant effect $(\mathrm{P}<0.05)$ with a negative sign which indicated the reduction of extraction efficiency with an increase of salt content.

Extraction time is one of the parameters that impact the extraction efficiency. A range of extraction time varying from $5-25$ min has been studied in this SBSE and the results are shown in Figure 2 (b) and Figure 2 (c). The extraction time has a positive effect upon extraction and increasing the extraction time caused the increase of the extraction recovery of the target triazines.

The multi-response optimization process was done by selecting the Minitab software profile for the selection of optimum conditions of the SBSE. Based on the optimization plot in Figure 3, the suggested optimum conditions suggested were set as: $8.5(\mathrm{pH})$, no addition of $\mathrm{NaCl}, 25 \mathrm{~min}$ (extraction time), and 24 min (desorption time). Three additional experiments were carried out under the optimal conditions, in which a good agreement between the calculated and experimental responses was obtained ( $97.5 \% \mathrm{ER})$ with $3.8 \%$ of RSD value.

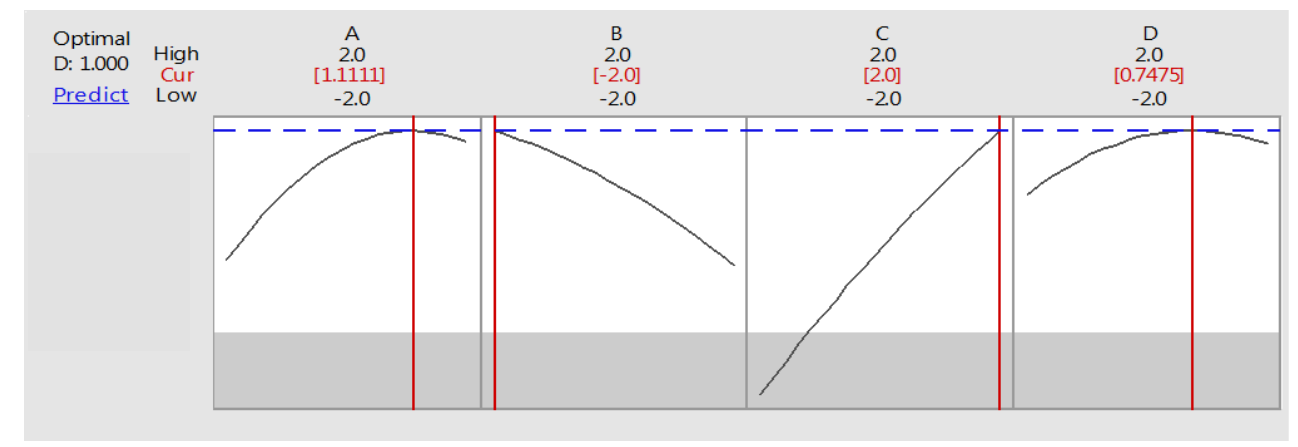

Figure 3. The optimization plots for the central composite design.

\section{Method validation}

Under the optimized conditions, analytical performance of the proposed method was evaluated and the results are summarized in Table 3. A good linearity was obtained in a concentration range of $0.10-100 \mu \mathrm{gL}^{-1}$ with correlation of determination $\left(\mathrm{R}^{2}\right)$ ranging from $0.9991-0.9995$. The LODs and LOQs were calculated as the concentration corresponding to signal-to-noise ratios of 3 and 10 respectively. The LODs and LOQs of three triazines were found to be ranging from $0.015-0.023 \mu \mathrm{gL}^{-1}$ and $0.047-0.060 \mu \mathrm{g} \mathrm{L}^{-1}$, respectively, which were lower than the maximum residue limit (MRL) set by European Union (EU) for triazines (a maximum level of $0.10 \mu \mathrm{gL}^{-1}$ of a pesticide in water samples). The RSDs for three target analytes were in the range of $4.1-7.5 \%\left(\mathrm{c}=10 \mu \mathrm{gL}^{-1}\right)$.

Pan et al. [1] used stir bar sorptive extraction (SBSE) coupled with pulse glow discharge-ion mobility spectrometry (PGD-IMS) for the analysis of triazine herbicides in water samples. The LODs ranged from 0.006 to 0.015 $\mu \mathrm{gL}^{-1}$. Wu et al. [12] used solid-phase microextraction with graphene-coated fiber for the analysis of triazine herbicides in water samples. The LODs ranged from 0.05 to $0.2 \mu \mathrm{gL}^{-1}$. Liu et al. [13] used effervescent tablet assisted on-site liquid phase microextraction for the determination of five triazine herbicides in water by an ultrahigh pressure liquid chromatography tandem mass spectrometer. The LODs ranged from 0.002 to $0.008 \mu \mathrm{gL}^{-1}$. It is important to note that the detection limits achieved by the proposed method are better than or comparable to those reported previously using different extraction techniques. 
Table 3. Analytical performance of the proposed PDMS coated stir bar for the analysis of triazines

\begin{tabular}{|c|c|c|c|c|c|c|}
\hline Analytes & $\begin{array}{l}\text { Linear } \\
\text { Equation }\end{array}$ & $\begin{array}{l}\text { Linear } \\
\text { Range } \\
\left(\mu g L^{-1}\right)\end{array}$ & $\begin{array}{c}\text { Correlation } \\
\text { Coefficient } \\
\left(\mathbf{R}^{2}\right)\end{array}$ & $\begin{array}{c}\text { Limit of } \\
\text { Detection } \\
\left(\mu \mathrm{g} \mathrm{L}^{-1}\right)\end{array}$ & $\begin{array}{c}\text { Limit of } \\
\text { Quantification } \\
\left(\mu g \mathrm{~L}^{-1}\right)\end{array}$ & $\begin{array}{l}\text { Repeatability } \\
\text { (\%RSD) }\end{array}$ \\
\hline Atrazine & $y=2.34 x+3.24$ & $0.1-100$ & 0.9991 & 0.015 & 0.047 & 7.5 \\
\hline Ametryn & $y=1.05 x+3.50$ & $0.1-100$ & 0.9995 & 0.023 & 0.060 & 4.1 \\
\hline Cyanazine & $y=1.23 x+8.01$ & $0.1-100$ & 0.9993 & 0.018 & 0.055 & 5.0 \\
\hline
\end{tabular}

\section{Quantification of partition coefficient and enrichment factor}

SBSE is a sample preparation technique based on sorptive extraction. The sorptive extraction process is by nature an equilibrium technique, where the extraction of solutes from the liquid sample phase into the extraction medium is controlled by the partition coefficient $(\boldsymbol{K})$. This coefficient is dependent upon the phase ratio, and thus on the amount of extraction phase used.

The coefficient, $K$ shows that to obtain high $\mathrm{EF}$, a low $\mathrm{V}_{\mathrm{e}} / \mathrm{V}_{\mathrm{s}}$ ratio and high partition coefficient are required. SBSE may be applied to medium polarity and non-polar analytes and to those whose polarities can be reduced before extraction. The major factor affecting EF was the partition coefficient. The EF was directly related to $K$.

In the present study, the amount of atrazine, cyanazine, and ametryn in the PDMS sorbent were calculated using the peak area ratio measurements and the calibration curves of the standards only. Data of the enrichment factor for the target analytes were determined and presented in Table 4 which indicates the correlations between the enrichment factor and partition coefficient. The enrichment factor of cyanazinne was slightly lower as compared to atrazine and ametryn. This was due to the higher solubility of cyanazine in the sample aqueous phase thus reducing its partition into the extraction phase.

Table 4. Analytical performance in term of enrichment factor and partition coefficient

\begin{tabular}{lcc}
\hline Triazines & Enrichment factor, $\mathbf{E F}^{\mathbf{a}}$ & Partition coefficient, $\boldsymbol{K}$ \\
\hline Ametryn & 334 & 614 \\
Atrazine & 316 & 581 \\
Cyanazine & 281 & 511 \\
\hline${ }^{\text {a }}$ Enrichment was determined at concentration of $5.0 \mu \mathrm{u} \mathrm{L} \mathrm{L}^{-1}$ for all analytes
\end{tabular}

\section{Analysis of real samples}

In most microextraction techniques, the efficiency of extraction by SBSE can be affected by the composition of the matrix. High levels of dissolved or suspended organic matter contained in real water samples may disrupt analytes from extraction to the stir bar, thus the extraction performance changes from sample to sample.

The relative recovery (RR) was investigated to study the matrix effect towards the extraction efficiency of respective devices [14]. To further evaluate the practical applicability of the proposed method, extraction and analysis were performed on six water samples that were collected from paddy fields (three stations from organic plots and three stations from conventional plots). In order to identify the influence of matrix, the extraction recovery of triazines from real samples were compared with the extraction recovery from ultrapure water sample. The proposed method achieved relative recoveries in the range of $95-98 \%$ with RSD values between $3 \%$ and $6 \%$.

\section{Conclusion}

A study on the extraction of triazines by using a homemade PDMS-coated stir bar was successfully carried out. By applying the experimental design, behaviour of each variable and their interaction during the extraction and 
desorption procedures were discriminated using the ANOVA test. In this study, the SBSE parameters affecting the extraction recovery have been optimized as follows: sample at $\mathrm{pH} 8.5$, no addition of $\mathrm{NaCl}, 25$ minutes of extraction time, and 24 minutes of desorption time. A low $\mathrm{V}_{\mathrm{E}} / \mathrm{V}_{\mathrm{S}}$ ratio and high partition coefficient offered a high enrichment factor. The enrichment factor was directly related to the partition coefficient. Overall, the proposed procedure was proven to be a good alternative methodology for the determination of selected triazine residues in environmental samples, being a simple, fast, reproducible, effective and an environmentally-friendly analytical method.

\section{Acknowledgments}

We highly express our sincere gratitude to Universiti Kebangsaan Malaysia for the research facilities and the Ministry of Education (MOE) for the funding this work under the SLAB/SLAI scheme.

\section{References}

1. Pan, C., Zou, N., Yuan, C., Liu, S., Han, Y., Li, Y. and Zhang, J. (2016). Coupling of multi-walled carbon nanotubes/polydimethylsiloxane coated stir bar sorptive extraction with pulse glow discharge-ion mobility spectrometry for analysis of triazine herbicides in water and soil samples. Journal of Chromatography A, 1457: 14-21.

2. Chen, L., Wen, Y., Chen, L., Li, J. and Liu, D. (2014). Recent advances in solid-phase sorbents for sample preparation prior to chromatographic analysis. Trends in Analytical Chemistry, 59: 26-41.

3. Sharif, M., Khodadoust, S., Mousavi, A. and Mahmoudi, R. (2017). Preconcentration of carbamate insecticides in water samples by using modified stir bar with $\mathrm{ZnS}$ nanoparticles loaded on activated carbon and their HPLC determination : Response surface methodology. Microchemical Journal, 130: 64-70.

4. Lei, Y., He, M., Chen, B. and Hu, B. (2016). Polyaniline / cyclodextrin composite coated stir bar sorptive extraction combined with high performance liquid chromatography-ultraviolet detection for the analysis of trace polychlorinated biphenyls in environmental waters. Talanta, 150: 310-318.

5. Zhang, H., Low, W. P. and Lee, H. K. (2012). Evaluation of sulfonated graphene sheets as sorbent for microsolid-phase extraction combined with gas chromatography-mass spectrometry. Journal of Chromatography A, $1233,16-21$.

6. Baltussen, E., Sandra, P., David, F. and Cramers, C. (1999). Stir bar sorptive extraction (SBSE), a novel extraction technique for aqueous samples: Theory and principles. Journal of Microcolumn Separations, 11(10): 737-747.

7. Ayazi, Z. and Matin, A. A. (2016). Development of carbon nanotube-polyamide nanocomposite-based stir bar sorptive extraction coupled to HPLC-UV applying response surface methodology for the analysis of bisphenol a in aqueous samples. Journal of Chromatographic Science, 4: 1-10.

8. Manuel, J. and Nogueira, F. (2015). Stir-bar sorptive extraction : 15 years making sample preparation. Trends in Analytical Chemistry, 71:214-223.

9. Blasco, C., Fernández, M., Picó, Y. and Font, G. (2004). Comparison of solid-phase microextraction and stir bar sorptive extraction for determining six organophosphorus insecticides in honey by liquid chromatography mass spectrometry. Journal of Chromatography A, 1030: 77-85.

10. Lei, Y., Chen, B., You, L., He, M. and Hu, B. (2017). Polydimethylsiloxane / MIL-100 ( Fe ) coated stir bar sorptive extraction-high performance liquid chromatography for the determination of triazines in environmental water samples. Talanta, 175: 158-167.

11. Ayazi, Z. and Rafighi, P. (2015). Preparation and application of a carbon nanotube reinforced polyamide-based stir bar for sorptive extraction of naproxen from biological samples prior to its spectrofluorometric determination. Analytical Methods, 7: 3200-3210.

12. Wu, Q., Feng, C., Zhao, G., Wang, C. and Wang, Z. (2012). Graphene-coated fiber for solid-phase microextraction of triazine herbicides in water samples. Journal of Separation Sciences, 35: 193-199.

13. Liu, D., Liu, X., Shen, Z., Wang, P., Liu, C. and Zhou, Z. (2014). Effervescence assisted on-site liquid phase microextraction for the determination of five triazine herbicides in water. Journal of Chromatography A, 1371: 58-64.

14. Sanagi, M. M., See, H. H., Ibrahim, W. A.W. and Naim, A. A. (2010). Determination of triazine herbicides using membrane-protected carbon nanotubes solid phase membrane tip extraction prior to micro-liquid chromatography. Journal of Chromatography A, 1217: 1767-1772. 